\title{
“Onde manda capitão, não governa marinheiro"? \\ O trabalho marítimo no rio da Prata, 1890-1920*
}

\section{Laura Gabriela Caruso**}

Resumo: Este artigo propõe reconstruir a organização e o processo de trabalho marítimo a bordo, nas dimensões da história dos trabalhadores marítimos do rio da Prata, suas características (composição das seções, das tarefas e das qualificações) e condições de trabalho entre os anos de 1890 e 1920. Ao constituir um grupo de visibilidade significativa, tanto pela importância da atividade na estrutura econômica nacional como por suas ações sindicais, nos interessa aqui o estudo de uma das dimensões da experiência dos trabalhadores embarcados, desenvolvida a bordo das embarcações que operavam no interior do porto ou que navegavam rio acima até Mato Grosso, Assunção e as cidades do litoral argentino ou da Patagônia.

Palavras-chave: trabalho marítimo (Argentina), processo do trabalho, condições do trabalho

Abstract: This work aims to rebuild forms of work on board, organization and maritime, workflow as one of the dimensions of the history of maritime workers in the río de la Plata, their characteristics (composition of sections, tasks and qualifications) and working conditions in the years ranging from 1890 to 1920 . To the have formed a group significant visibility, both central activity in national economic structure and its Union actions addressed here study of one of the dimensions of the experience of the on-board workers, the labour, developed aboard vessels operating within the port or they that sailed upstream until Matto Grosso, Asunción in Paraguay, the cities of the coast or the Patagonian coast.

Keywords: maritime work (Argentina), labor process, onboard labor conditions

O transporte marítimo foi uma atividade central na estrutura econômica da Argentina e no processo de sua incorporação à economia mundial capitalista, encontrando-se a cargo dos trabalhadores marítimos. O desenvolvimento e a consolidação de uma infraestrutura de transporte que permitisse a exportação e comercialização da produção nacional incluíram, além da construção da rede ferroviária, a constituição de uma frota mercante fluvial. Os operários que navegavam por rios e costas consistiram numa das engrenagens fundamentais na atividade econômica e tiveram um lugar de importância no processo de formação da classe

\footnotetext{
* Tradução de Márcia Carolina de Oliveira Cury. Agradeço a colaboração do Prof. Victor Wagner Neto de Oliveira para a realização desta tradução.

** Instituto de Altos Estudios Sociales - Universidad Nacional de San Martín (IDAES-UNSAM) Universidad de Buenos Aires-CONICET. E-mail: lauracaruso@gmail.com
} 
operária argentina. A posição estratégica do seu trabalho fortaleceu sua colocação com relação às empresas do setor e aos sucessivos governos na hora de fazer valer suas reivindicações. Esta posição estrutural privilegiada e o desenvolvimento de uma organização sindical unificada entre as diferentes seções possibilitaram a realização exitosa de ações de luta e foram a base para o controle do trabalho, sua renda e suas condições na segunda década do século XX.

Durante os primeiros anos do século houve diversas tentativas de constituir uma organização sindical unificada por parte dos operários embarcados. Assim demonstra a ação conjunta das Sociedades de Marinheiros e de Foguistas, e o surgimento, em 1907, da Liga Obrera Naval. Depois dessas experiências, em 1910, foi criada a Federación Obrera Marítima (FOM), um dos primeiros sindicatos por ramo, de caráter nacional, à frente do qual se encontravam militantes operários da corrente sindicalista. A FOM chegou a ser uma das organizações mais importantes do movimento operário argentino nas primeiras décadas do século XX e um dos pilares da Federación Obrera Regional Argentina, Nono Congresso (FORA IX), a principal central sindical nesses anos, dirigida pela mesma corrente ${ }^{1}$.

No entanto, este significativo lugar na realidade histórica do trabalho na Argentina não encontrou seu correlato nas produções historiográficas. Em contraste com a extensa bibliografia existente em torno dos trabalhadores ferroviários, um setor evidentemente chave do transporte, os estudos históricos das últimas décadas na Argentina prestaram escassa ou nula atenção aos problemas e processos relacionados com os operários marítimos. Sua experiência no trabalho e na política sindical é uma

\footnotetext{
${ }^{1}$ O sindicalismo foi uma corrente dominante entre os trabalhadores e suas organizações na década de 1910, sob a direção da FOM e da FORAXI. Centrando-se no controle operário sobre as condições da própria atividade, as lutas dirigidas pelos sindicalistas da FOM desafiaram o poder patronal sobre 0 processo de trabalho, a seleção da mão de obra e as condições de trabalho. Marcada por um forte obreirismo, anti-intelectualismo e apoliticismo, reivindicaram a ação direta e a autoeducação operária por meio da luta sindical. Afirmavam o sindicato como a organização privilegiada para a direção operária, em detrimento do partido político. Na Argentina, os sindicalistas se constituíram em uma corrente autônoma em 1906, ao serem expulsos do Partido Socialista, ao qual questionavam por seu parlamentarismo e sua escassa penetração nos sindicatos. À frente de importantes organizações sindicais, sua orientação política convergiu para posturas mais corporativo-economicistas, na defesa incondicional da ferramenta sindical, o sindicato, e abandonando progressivamente o confronto aberto, para substituí-lo por uma tática pragmática e centrada na negociação. Ver KERSFFELD, Daniel. George Sorel: apóstol de la violencia. Buenos Aires: Signo, 2005; BELKIN, Alejandro. Sobre los orígenes del sindicalismo revolucionario en Argentina. Departo. Historia, Buenos Aires, CCC, 2007; BERTOLO, Maricel. Una propuesta gremial alternativa: el Sindicalismo Revolucionario (1904-1916). Buenos Aires: CEAL, 1993; CAMPO, Hugo Del. El sindicalismo revolucionario (1905-1940). Buenos Aires: CEAL, 1986.
} 
história ainda por se escrever. Nessa perspectiva, o presente artigo avança no conhecimento das formas do trabalho marítimo, a partir da reconstrução da sua materialidade primeira, do processo de trabalho e da organização trabalhista, assim como das condições que regiam o trabalho a bordo das embarcações fluviais do rio da Prata.

O estudo dos modos e formas de trabalho a bordo, sua organização e suas transformações, possibilita o conhecimento do desenvolvimento cotidiano do trabalho dos operários nas embarcações de cabotagem, e permite assim reconstruir uma das múltiplas dimensões da história de um grupo operário que teve no conjunto dos trabalhadores um papel importante para o desenvolvimento sindical e político da classe operária argentina nas primeiras décadas do século XX. Os documentos que permitem desenvolver a análise são variados e poucas vezes visitados na historiografia local. Os jornais sindicais, como La Unión del Marino, El Boletín del Obrero Mecánico e El Maquinista Marítimo, junto com outras publicações estatais, como o Boletín del Departamento Nacional del Trabajo, assim como leis e regulamentos da Prefectura Geral de Puertos e censos nacionais correspondentes ao período em questão, são os documentos que sustentam a presente análise.

Os trabalhadores marítimos foram marinheiros de diversas categorias e funções, foguistas, maquinistas, oficiais, moços, cozinheiros, ajudantes de máquina ou de coberta que, embarcados em navios mercantes pertencentes em sua maioria a empresas de bandeira nacional, realizavam travessias pelos rios e costas da Argentina e países limítrofes. Estes realizavam suas tarefas diárias a bordo de grandes vapores, veleiros, rebocadores e lanchas, entre as muitas embarcações que navegavam a bacia do Prata ou operavam no interior do porto de Buenos Aires. Eram operários que manejavam, mantinham, limpavam ou habitavam os barcos mercantes, realizando a bordo diversas tarefas que requeriam diferentes qualificações. O controle da entrada e saída dos barcos dos portos argentinos, em especial aqueles portos artificiais que requeriam o uso de rebocadores para o atraque dos transatlânticos ou outros barcos de grande calado, como era o caso de Buenos Aires, agrega um elemento explicativo da contundência das ações destes trabalhadores. Tal como afirmou o historiador 
Edgardo Bilsky: "Dominar as vias de comunicação, o porto, é dominar o fluxo da vida econômica. E isto será rapidamente compreendido pelo movimento operário" ${ }^{2}$.

O cenário mais amplo desta história foi o rio da Prata e seu principal porto, Buenos Aires, a partir do qual se estabeleceram conexões regionais, nacionais e internacionais, constituindo um espaço de expressão precoce e intensa do conflito operário-patronal e sendo também o lugar de onde trabalhadores e empresários, através de suas organizações corporativas e políticas, traçaram suas estratégias.

As embarcações foram o cenário particular do trabalho a bordo. Estes barcos provinham de lugares tão diversos como o Mato Grosso, Assunção, o Alto Paraná, os povos e cidades do Litoral, Montevidéu e outros portos uruguaios, a costa patagônica ou a brasileira, ou os tinham como destino. Havia também grande quantidade de outras embarcações menores que operavam dentro das instalações do porto, no transbordo de mercadorias, passageiros ou tripulantes.

Cabe destacar algumas das características particulares do trabalho marítimo, já que influenciaram em grande medida na conformação da experiência do trabalho. Assim, sua forte sazonalidade, marcada pelos ritmos da produção agropecuária, fazia com que na época da colheita, durante os meses de verão, a atividade de carga e descarga dos produtos a serem vendidos nos mercados internacionais fosse mais intensa. Isto elevava a demanda de mão de obra no porto e a bordo, gerando uma conjuntura de auge do emprego, propícia também para estabelecer ações de luta diversas ${ }^{3}$. De fato, a maioria das greves declaradas pelas organizações sindicais marítimas se deu entre dezembro e fevereiro. No período aqui considerado, iniciou-se uma greve no final de 1890, declarada pela Sociedad de Marineros, e se encerra - este período - com uma greve iniciada em fevereiro de 1920, que acabará por ser uma das greves mais prolongadas da história do país.

Em segundo lugar, um traço que por característico pode parecer óbvio, foi a contratação predominante, quase exclusiva, de homens adultos para realizar os trabalhos a bordo. Isso fez do trabalho marítimo um âmbito masculino, pelo tipo de tarefas a realizar, pela força e resistência requeridas, e pela particularidade de ser um

\footnotetext{
2 BILSKY, Edgardo. La F.O.R.A. y el movimiento obrero/1. Buenos Aires: CEAL, 1985, p. 53.

3 PIANETTO, Ofelia. Mercado de trabajo y acción sindical en la Argentina, 1890-1922. Desarrollo Económico. v. 24, n. 94, julio-septiembre 1984, p. 297-307.
} 
trabalho que se realizava em um tempo e um espaço distantes do lar, em que se embarcava às vezes por vários dias ou semanas, de acordo com o caso.

Terceiro, o trabalho marítimo esteve também marcado pela grande mobilidade internacional de sua mão de obra durante todo o período, atravessado pela Grande Guerra e pelas crises econômicas. Imigrantes italianos e croatas, entre muitos outros, foram parte fundamental das tripulações das frotas fluviais. Cabe destacar que a partir da Lei de Cabotagem, sancionada no ano de 1910, que exigia fosse uma porcentagem destas de nativos ou naturalizados argentinos, ocorreu uma tendência à argentinização, mais acentuada entre os oficiais, mas igualmente existente entre a tripulação ${ }^{4}$. No caso dos trabalhadores da Sala de Máquinas, apenas em 1915, com a incorporação de um novo regulamento, foi estipulada a nacionalidade dos maquinistas, os quais deveriam ser cidadãos argentinos no caso do chefe de sala ou primeiro maquinista.

Por último, e com relação à condição de imigrantes da maioria dos operários embarcados, isto mesmo somado à própria natureza da atividade fez do trabalho marítimo uma experiência regional, a qual não admitia fronteiras nacionais. Os trabalhadores que realizavam a navegação comercial sobre as águas do Uruguai, Paraguai, Brasil e Argentina transitavam em suas fronteiras geográficas e políticas. A viagem tornava difusas tais divisões, fazendo dos marítimos os trabalhadores internacionais por antonomásia. A dupla condição de imigrantes e trabalhadores a bordo possibilitava uma percepção mais imediata de pertencimento a um grupo humano sem fronteiras, o qual compartilhava condições de existência e de exploração. Como afirma Vitor Wagner Neto de Oliveira, o fato de serem internacionais favorecia nestes trabalhadores certas posições internacionalistas, dotando-os de uma condição de possibilidade, necessária mas não suficiente, para o desenvolvimento de uma identidade classista caracterizada por um internacionalismo, em tensão com outras

\footnotetext{
${ }^{4}$ CLIMENT, Aurelio González y CLIMENT, Anselmo González. Historia de la Marina Mercante Argentina. Buenos Aires, 1972, tomo IV. A Ley de Cabotaje no 7.049, de 1910, estipulou em primeiro lugar que a navegação fluvial ou de cabotagem, entre portos interiores, ficava reservada a embarcações de bandeira nacional, as quais obrigatoriamente deviam ter um capitão ou patrão argentino, assim como a quarta parte da sua tripulação. Ao pertencer ao pavilhão nacional, uma embarcação podia, a partir desta lei, não pagar certos direitos de entrada, farol, balizas, saúde e visto consular em portos nacionais e de alguns países limítrofes. Esta lei foi substituída, em 1918, pela Lei no 10.606.
} 
identidades, como a profissional, a étnico-cultural ou a nacional, sobre as que prevaleceram nos primeiros anos do século $\mathrm{XX}^{5}$.

\section{A BORDO DAS EMBARCAÇÕES FLUVIAIS}

O trabalho de tripulantes e oficiais se desenvolveu em barcos a vapor, veleiros, lanchas, barcaças, chalanas, rebocadores e outros tipos de embarcações. Sua estrutura, seu maquinário e demais características esboçaram tarefas e funções, sendo o substrato material das formas de trabalho a bordo. Sob a tensão do local de trabalho, operários e patrões delinearam concepções e valores a partir dos interesses que se contrapunham no trabalho cotidiano, organizando-se e atuando em torno daqueles. Assim, no cenário particular do trabalho marítimo condensaram-se relações econômicas, sociais e políticas significativas que tornam necessário seu estudo. Enquanto primeira aproximação ao universo do trabalho, a reconstrução do processo e organização do trabalho e suas mudanças permitem conhecer a experiência operária no campo da produção mesma, destacando o caráter conflituoso do trabalho, da tecnologia, suas relações e transformações ${ }^{6}$. Desta forma, o processo de trabalho, enquanto ferramenta conceitual e metodológica, se constitui em uma dimensão explicativa importante para se compreender as formas de exploração, a experiência do trabalho, suas tensões e características, bem como as formas sindicais e políticas desenvolvidas pelos trabalhadores.

$\mathrm{Na}$ hora de conhecer as condições nas quais se realiza o trabalho de milhares de operários embarcados, de um ponto de vista qualitativo, analisando o processo de trabalho e suas formas particulares, um dos aspectos fundamentais a considerar é sua base técnica, a estrutura material sobre a qual se desdobrou a exploração do trabalho e suas modificações. A máquina a vapor, a multiplicação do número de caldeiras, o uso de turbinas e de motores diesel, assim como os cascos de ferro ou aço e a hélice, foram algumas das mudanças mais importantes que se impuseram na indústria marítima mundial e também na Argentina. As embarcações a motor e com casco

\footnotetext{
${ }^{5}$ OLIVEIRA, Vitor Wagner Neto de. Entre o Prata e Mato Grosso: uma viagem pelo mundo do trabalho marítimo de 1910 a 1930 (Buenos Aires, Montevidéu, Assunção e Corumbá). UNICAMP, Campinas, 2006. ${ }^{6}$ LOBATO, Mirta. La vida en las fábricas. Trabajo, protesta y política en una comunidad obrera, Berisso (1904-1970). Buenos Aires: Prometeo, 2001.
} 
metálico foram utilizadas de forma generalizada em nosso país nas últimas décadas do século XIX. Caso se observe a tonelagem de registro, ou seja, a capacidade de carga em vapores ou veleiros, torna-se evidente o predomínio dos primeiros. Já em 1880, 65,3\% da tonelagem comercializada foram transportados em barcos a vapor; em 1914, a porcentagem ascendia a $90 \%{ }^{7}$. A utilização da máquina a vapor apresentou também alguns problemas, como, por exemplo, o alto consumo de carvão, pois, além de ter um custo elevado, ocupava um grande espaço para armazená-lo.

Essas transformações geraram por sua vez uma redução dos tempos de viagem e uma maior qualidade, em função de uma maior regularidade e segurança. Também possibilitaram triplicar a capacidade média do porão ou carga, que passou de 348 a 1.121 toneladas entre 1880 e 1914 . Ao mesmo tempo, a tripulação média necessária a bordo diminuiu, entre 1895 e 1914, de 20 para 8 tripulantes por barco. Desta forma, as mudanças se traduziram em um substancial aumento da produtividade do trabalho, tanto na velocidade como na capacidade do transporte, ao mesmo tempo que tornaram possível uma redução da quantidade de força de trabalho empregada a bordo ${ }^{8}$.

A passagem da navegação a vela para a navegação a vapor foi uma das mudanças fundamentais na indústria marítima mundial. Com ela se avançou na mecanização do trabalho, já que o motor deu uma nova base objetiva ao processo de trabalho na navegação, impondo formas e ritmos, determinando em boa medida sua organização e a existência de diversas categorias e tarefas. Apareceram assim os maquinistas, foguistas, auxiliares, entre outros, que operavam, realizavam tarefas de manutenção, alimentavam, reparavam e limpavam a máquina.

Junto com a implementação da máquina a vapor ocorreram outras mudanças, entre as quais a mais importante foi a passagem da madeira para o metal na construção do casco e da estrutura das embarcações. A utilização da madeira, por suas características, limitava a capacidade das embarcações e as tornava mais instáveis e

\footnotetext{
${ }^{7}$ Terceiro Censo Nacional, levantado em 1o de junho de 1914, tomo 1ํㅡ, Bs. Aires, Talleres Gráficos de L.J. Rosso, 1916-1917.

${ }^{8}$ Dados de elaboração própria, a partir dos censos nacionais: Segundo Censo da República, Buenos Aires, Talleres Tipográficos de la Penitenciaría Nacional, 1898, y Terceiro Censo Nacional, levantado em 10 de junho de 1914, tomo 10, Talleres Gráficos de L. J. Rosso, Bs. Aires, 1916-1917.
} 
precárias, por sua dificuldade em conseguir estanquidade ${ }^{9}$. Após algumas construções mistas, o ferro se impôs por suas vantagens e só será substituído pelo aço, já entrado o século XX. Em 1895, 88\% dos vapores recenseados tinham casco de ferro; em 1914, 92\%. O novo material permitiu a construção de buques de maiores dimensões, aumentando a capacidade de carga e o volume de mercadorias que podiam ser transportadas em uma viagem. O ferro e a maior potência gerada pelas máquinas a vapor ou outros motores tornaram possível o aumento da velocidade. Mais carga em menos tempo, ambos os fatores tornaram mais produtivo o trabalho a bordo.

Houve outras inovações que visavam melhorar o funcionamento da máquina a vapor e a utilização do espaço a bordo. Uma destas, que ajudou a aumentar a pressão e a potência do motor, foi a mudança na forma das caldeiras, que de quadradas passaram a ser cilíndricas ou tubulares. Outras modificações apontavam para a diminuição do consumo de carvão e para o aumento da potência, chegando a estabelecer-se um sistema misto de máquina a vapor e de turbinas. Finalmente, a própria máquina a vapor foi trocada. Nos primeiros anos da década de 1910, começou a ser substituída pelo motor de combustão interna ou diesel, com o que, por não precisar de alimentação externa de nenhum tipo, permitiu suprimir caldeiras e carvoeiras, liberando espaço e capacidade para o transporte de uma quantidade maior de mercadorias. Ao mesmo tempo, por sua maior potência e velocidade, o motor a diesel encurtou em grande medida os tempos de viagem. Um indício da maior presença deste tipo de motores na frota mercante argentina consistiu na sanção do Regulamento de Condutores e Maquinistas de Motores Marinhos de Combustão Interna, realizada em 1912, por decreto do Poder Executivo Nacional ${ }^{10}$. O crescente aperfeiçoamento do motor a diesel significou um número cada vez maior de operários destinados a manejar, reparar, manter e limpar a máquina, processo que se viu demonstrado, por exemplo, na constituição da Federação de Trabalhadores de Combustão Interna, em abril de 1917, na região do Alto Paraná ${ }^{11}$.

\footnotetext{
${ }^{9}$ Qualidade de estanco, isto é, não vazar no casco e na coberta, o que se consegue calafetando as juntas das madeiras com estopa ou algodão impregnado em sebo ou piche.

${ }^{10}$ CLIMENT, A. G. y CLIMENT, A. G. op. cit. ; Recopilación de antecedentes que interesan a la Marina Mercante y Policía Marítimas, Bs. As., 1937, Ordenanza 2333, 27 noviembre 1912.

${ }^{11}$ La Unión del Marino (LUM) no 64, junio 1920, Boletín del Departamento Nacional del Trabajo (DNT); no 65, julio 1920 .
} 
Com relação à motivação de armadores e empresários para introduzir estas mudanças no processo de trabalho, é claro que as modificações e inovações na estrutura dos barcos responderam ao problema fundamental das empresas de navegação de cabotagem e das empresas marítimas em geral, que era o de reduzir os custos da viagem, encurtar seu tempo e acrescentar por sua vez os benefícios obtidos, e ao mesmo tempo, sobreviver e se impor à concorrência. Buscaram para isso formas, materiais, máquinas e equipamentos que tornaram mais reduzido o tempo de viagem e aumentaram a segurança, reduzindo possíveis perdas. A lógica subjacente não é outra senão a de aumentar a produtividade do trabalho, permitindo com tal aumento uma crescente reprodução ampliada de seus investimentos. Estas mudanças foram, além da necessidade da concorrência, uma arma política dos patrões, possibilitando o deslocamento de trabalhadores e o ataque ao seu poder e organização sindical. A Companhia de Navegação Argentina Nicolás Mihanovich foi uma das empresas marítimas que adotou essas inovações precocemente. Esta se converteu na empresa naval mais importante do tráfego de cabotagem no início do século $X X$, mediante um processo de concentração e centralização de capitais, a partir da incorporação da maioria de suas concorrentes por compras sucessivas, chegando a quase monopolizar as viagens pelo Litoral e pelas costas uruguaia e brasileira. Em sua frota figuraram as embarcações mais velozes e modernas, a maioria delas construída na Inglaterra.

Por outro lado, o avanço da mecanização do processo de trabalho implicou tornar independente da perícia humana o trabalho a bordo, e com isso, simplificou tarefas, ao mesmo tempo que criou novos ofícios ou categorias de trabalhadores e eliminou outras. As mudanças no processo de trabalho tiveram consequências para o trabalhador marítimo, entre as quais é possível identificar em primeira instância a redução do número de trabalhadores necessários. Isto pode ser mensurado a partir da quantidade de trabalhadores que constituíam a tripulação média por embarcação, a qual se reduziu de 20 para 8, entre 1895 e 1914. Do conjunto da tripulação, a mais afetada pelas transformações do processo de trabalho foi a seção da sala de máquinas. Comparando as informações que fornecem os censos para os anos de 1895 e 1914, a quantidade de foguistas foi reduzida em $42 \%$, enquanto o número de maquinistas diminuiu $40 \%$. 
Junto com a queda do número de trabalhadores a bordo, a incorporação de mudanças na base material do trabalho se traduziu no desaparecimento de certas ocupações. Por exemplo, a substituição da madeira pelo ferro como material do casco resultou na diminuição do número e da importância do ofício do calafate ${ }^{12}$. Por sua vez, nos barcos a motor já não eram necessários todos os conhecimentos, perícias e manobras relacionados ao velame, que constituíam até então parte central das tarefas dos marinheiros na coberta. Do mesmo modo, a incorporação de novas máquinas acarretou o aparecimento de novos trabalhadores, como os engraxadores, eletricistas e outros operários dedicados a manter e limpar as novas máquinas, assim como também gerou a diminuição e a progressiva eliminação de foguistas e carvoeiros, ao prescindir da alimentação externa do motor. Uma evidência desse processo constitui a carta de reivindicações das tripulações na greve do Alto Paraná, do início de 1918, no qual não aparecem foguistas nem carvoeiros, e sim o pessoal de motores de combustão interna e engraxadores ${ }^{13}$. Assim, o conjunto de mudanças e transformações no processo de trabalho marítimo e na sua organização derivou de múltiplos conflitos e medidas de luta por parte dos trabalhadores e suas organizações sindicais, desde inclusive os últimos anos do século XIX.

\section{EM VIAGEM: TAREFAS, CATEGORIAS E QUALIFICAÇÕES}

Há três classes de indivíduos: os que vivem, os que morrem, e os que estão no mar. (Provérbio popular)

As embarcações que percorreram rios e costas e aquelas que circulavam dentro do porto foram o local de trabalho de marinheiros e foguistas, entre muitos outros operários que constituíam as tripulações. Junto aos barcos a motor houve uma grande quantidade de embarcações menores a vela, com diferentes funções e estruturas, de acordo com o número e o tipo de velame. Goletas, balandras e paquebotes foram as mais características nos rios argentinos. A importância da navegação a motor desde 1880 e seu acelerado avanço constitui um dado da realidade histórica da navegação fluvial, sustentado nos números abaixo mencionados. No entanto, sua provada importância no país desde o fim do século XIX não impediu que a bordo dos veleiros

\footnotetext{
${ }^{12}$ Este trabalhador se encarregava de selar as juntas de madeira do casco com breu e estopa.

${ }^{13}$ LUM no 64, junio 1920, Boletín del DNT no 65, julio 1920.
} 
seguissem desenvolvendo seu trabalho uma grande quantidade de operários marítimos.

\section{Pessoal embarcado nas frotas de bandeira nacional}

\begin{tabular}{|c|c|c|c|}
\hline & Tripulação & Oficialidade & Total \\
\hline VELEIROS & \multicolumn{3}{|l|}{} \\
\hline 1895 & 4.865 & 1.967 & $\mathbf{6 . 8 3 2}$ \\
\hline 1914 & 3.925 & 5.329 & $\mathbf{9 . 2 5 4}$ \\
\hline VAPORES & & & \\
\hline 1895 & 3.854 & 211 & $\mathbf{4 . 0 6 5}$ \\
\hline 1914 & 8.301 & 1.545 & $\mathbf{9 . 8 4 6}$ \\
\hline
\end{tabular}

Elaboração própria com base em dados do Segundo Censo Nacional (1895) e Terceiro Censo Nacional (1914).

Em 1914, a quantidade de pessoal total embarcado designado aos veleiros e aos barcos a motor era similar. No entanto, ao considerar a diferença entre tripulação e oficialidade, surgem realidades contrastantes. A quantidade de operários embarcados ou tripulação foi maior nos vapores, enquanto nos veleiros, cada vez menos utilizados para as viagens de maior carga, predominavam os patrões de pequenas embarcações, os quais se classificavam como parte da oficialidade.

O trabalho desenvolvido por estes operários marítimos nos barcos que arribavam e zarpavam do porto de Buenos Aires, ou que operavam por seus canais e diques, estava organizado em diversas seções, com uma estrutura e categorias bem definidas. Do conjunto da tripulação, algumas nos parecem mais familiares, como podem ser os marinheiros ou maquinistas. No entanto, existiam múltiplas tarefas que se desenvolviam a bordo, organizadas nas seções de máquinas, a de coberta e a de câmara ou cozinha. Esta organização do trabalho segue sendo ainda hoje a estrutura básica do trabalho marítimo. Em cada uma dessas três seções havia uma hierarquia claramente estabelecida, que diferenciava a oficialidade da tripulação, e também as diversas tarefas e qualificações no interior de cada uma destas seções. Estes trabalhadores de rios, portos e costas pertenciam assim a uma das três seções nas quais se organizavam as tripulações fluviais. 


\section{EM COBERTA: MARINHEIROS E OFICIAIS}

Encarregada de realizar os serviços de navegação, as manobras do navio, o manejo do velame, as operações de carga e descarga de porões, a seção coberta estava composta pelo capitão e os oficiais auxiliares, junto com práticos ou baqueanos, e por uma tripulação constituída por diversas categorias de marinheiros. O marinheiro de maior experiência, o contramestre, coordenava à tripulação de coberta e controlava a eficaz realização das tarefas dos marinheiros, que consistiam na carga e descarga de mercadoria, o manejo de gruas, tarefas de amarração, controle dos porões, limpeza e manutenção da coberta, abertura e fechamento de escotilhas, extensão de toldos e guardas na ponte de navegação. Também se encarregavam da manutenção dos equipamentos, aparelhos e velames ou outros artefatos nos vapores, assim como de retocar a pintura e renová-la, e de lustrar os equipamentos e instalações de metal. Entre os marinheiros encontramos bodegueros ${ }^{14}$, timoneiros e faroleiros, de acordo com as tarefas às quais foram designados. Completavam a tripulação de coberta aqueles que manejavam os guinchos ou gruas, e os grumetes ou aprendizes de marinheiros. O contramestre recebia ordens do oficial chefe de coberta e as transmitia aos marinheiros, executando e supervisionando o plano de carga e descarga ${ }^{15}$.

O capitão era a figura mais complexa a bordo, por sua posição na relação com a empresa e/ou o armador e com a tripulação, assim como por suas funções e poderes, outorgados pelo direito de navegação. A carreira para chegar a ser a autoridade máxima a bordo transitava por diversas categorias: pilotín ${ }^{16}$, piloto, capitão de cabotagem ou fluvial, até capitão de ultramar $^{17}$. Para adquirir o título ou a habilitação expedida pela Prefeitura-Geral de Portos, o aspirante devia dar conta de uma ampla gama de conhecimentos, como astronomia, geografia do continente americano, trigonometria, meteorologia, direito comercial marítimo, língua, gramática e outros

\footnotetext{
${ }^{14}$ O bodeguero é o operário responsável pelo porão. Manteve-se aqui a denominação em espanhol, devido à dificuldade para encontrar um termo similar em português. [Nota da tradutora.]

${ }^{15}$ POTRONY, Yadira De Las Cuevas. Regulación Jurídica de la gente de mar. Aspectos significativos en el ordenamiento jurídico cubano. Revista Académica no 33, Equipo Federal de Trabajo, Cuba.

${ }^{16}$ Homem que servia nos buques como ajudante do piloto. [Nota da tradutora.]

${ }^{17}$ Recopilación de antecedentes que interesan a la Marina Mercante y Policía Marítimas, Bs. As., 1937, p. 386 a 389.
} 
mais. Os requisitos e exigências de ingresso dão a dimensão do trabalho altamente qualificado que constituía a profissão de capitão. No ano de 1917, o exame era realizado na Escola Nacional de Pilotos, de criação recente à época. Os aspirantes deviam ser maiores de idade, atestar 3 anos de experiência em navegação e contar com um certificado de aptidão física e outro de boa conduta ${ }^{18}$.

A responsabilidade máxima que tinha o capitão se aplicava, por lei, a todo o ocorrido a bordo, desde as manobras do buque em viagem e no porto, a gestão de atividades comerciais e a documentação necessária, a contratação e o manejo da tripulação, dos passageiros, das tarefas de carga e descarga, até as comunicações, e poderíamos seguir enumerando. Além disso, estava habilitado para ser representante legal do proprietário ou armador, e até mesmo em situações de exceção podia exercer funções públicas, tais como policiais (polícia de segurança, de navegação, judicial, sanitária, aduaneira, migratória), notariais (elaboração de testamentos e inventários) e de registro civil $^{19}$. Na regulamentação existente, a figura do capitão e sua autoridade apareciam fortemente reafirmadas, tanto como delegado da autoridade máxima, do Estado e como representante da empresa. Houve também uma especial ênfase na necessidade de respeitar sua autoridade e as disposições por ele determinadas, afirmando a disciplina a bordo e respeitando a escala de hierarquias sobre cuja base estava organizado o trabalho ${ }^{20}$.

A posição complexa do capitão em particular, e da oficialidade em geral, com relação ao conjunto dos trabalhadores embarcados não impediu que as organizações sindicais do pessoal hierárquico se aliassem em certas conjunturas com os sindicatos da tripulação, como ocorreu entre 1916 e 1921, quando estes desenvolveram uma ação conjunta de confronto com as empresas. O fato de possuir um maior conhecimento do processo de trabalho e de sua organização, somado ao contato fluido e direto com os armadores, deixava nas mãos da oficialidade a tomada de decisões vitais referentes ao trabalho a bordo. Este foi um dos motivos pelo qual a unidade de ação entre a FOM e o Centro de Capitães e outros sindicatos de oficiais mostrou-se decisiva para o desenvolvimento exitoso das lutas operárias nesses anos.

\footnotetext{
${ }^{18}$ Ibidem. p. 402 a 420. Programa de exámenes para capitanes, pilotos, pilotines y patrones de 1906, y ampliación de mayo de 1911.

${ }^{19}$ BLOCH, Roberto. La figura del Capitán. Revista Marítima, abril 1999.

${ }^{20}$ Recopilación de antecedentes... p. 388-389.
} 
A quantidade de oficiais necessários era estipulada para cada embarcação de acordo com a sua tonelagem e função. Os oficiais de primeira, segunda ou terceira categoria eram encarregados de diversas tarefas. O primeiro oficial, o chefe de coberta, estava a cargo da execução de tudo o que era decidido pelo capitão, em assuntos como o diagrama e execução do plano de carga e estiva, manutenção dos instrumentos e equipamentos de coberta, condução do pessoal, tarefas administrativas como a designação de turnos e de horas extras. O segundo oficial era responsável pela atualização das cartas de navegação. O terceiro oficial, além de assistir os demais, devia garantir o cuidado e manutenção do equipamento de salvamento e incêndio, os botes e balsas salva-vidas, extintores portáteis, sistema de alarmes e detectores de incêndio e sistemas fixos de extinção de incêndios ${ }^{21}$.

Os capitães de barcos pequenos eram chamados patrões. Estes, responsáveis por um barco, chata ou outra embarcação menor, podiam ser proprietários ou estar empregados por uma empresa de navegação. Constituíam um grupo particular dentro da estrutura sindical marítima, já que, ainda que fossem considerados pilotos de menor categoria, a maioria se organizou sindicalmente junto com a tripulação. Capitães e patrões eram responsáveis pela conformação da tripulação e da entrega da lista correspondente à Prefeitura e à Aduana ${ }^{22}$.

\section{NO CORAÇÃO DO BARCO: A SALA DE MÁQUINAS}

\footnotetext{
...hoje não se move uma coisa a bordo sem que o maquinista tenha que intervir; hoje podemos dizer que a navegação é mecânica... O maquinista a bordo é o factotum, podemos dizer, e se não, experimenta: que os turcos não funcionam bem, lá vai o maquinista; que a luz elétrica anda mal, o maquinista tem de ir ver o que há; que o molinete não está bem, lá vai o maquinista... Mas ninguém se lembra de que lá embaixo, no estômago do buque, quase na quilha fechados, vão uns quantos homens velando pela segurança de todos... ${ }^{23}$
}

A direção e condução da máquina motor e os mecanismos auxiliares do buque, incluindo os sistemas elétricos, eram exercidos a partir da sala de máquinas. Ali

\footnotetext{
${ }^{21}$ Recopilación de antecedentes... p. 388.

${ }^{22}$ Recopilación de antecedentes... tomo 3, p. 212.

${ }^{23}$ El Maquinista Marítimo, 1ㅇ mayo 1902, p. 1, "Los maquinistas navales mercantes".
} 
trabalhavam foguistas, carvoeiros, caldeireiros, pañoleros ${ }^{24}$, limpadores, eletricistas, engraxadores, mecânicos e ajudantes, os quais, em turnos de 4 a 6 horas, se dedicavam a alimentar caldeiras, a vigiar, limpar e manter a maquinaria.

O chefe ou primeiro maquinista era responsável pelo funcionamento e manutenção da máquina principal e das auxiliares, da designação dos turnos e horas extras, e do cálculo de consumo de combustível e água para alimentar o motor. Devia ainda coordenar as reparações de envergadura com as oficinas correspondentes e com o armador. Outras tarefas, como vigiar o funcionamento de caldeiras e máquinas auxiliares, a manutenção do equipamento elétrico e as reparações menores, estavam a cargo do segundo oficial, com a colaboração de um terceiro oficial, se necessário. Os maquinistas precisavam da prévia e expressa autorização do capitão para qualquer modificação, tanto para reparar defeitos como para alterar o regime normal da marcha do motor.

Para ser maquinista marítimo era necessário se submeter a um exame na Prefeitura, que incluía conhecimentos de aritmética, geometria, álgebra, física, desenho e informação sobre caldeiras e acessórios, dependendo da categoria a que se buscava ascender ${ }^{25}$. Desde 1898 o ofício estava regulamentado ${ }^{26}$, definindo assim a quantidade de maquinistas e foguistas para cada embarcação, de acordo com a potência da máquina e dos turnos e guardas a cobrir ${ }^{27}$. No entanto, houve reiteradas demandas do sindicato de maquinistas devido ao descumprimento desse regulamento, denunciando a quantidade insuficiente de maquinistas diplomados ${ }^{28}$.

De acordo com o regulamento, modificado em 1907 e 1915, todos os postulantes a maquinista deviam se submeter a um exame. As categorias eram: condutor de máquinas, ajudante, primeiro, segundo e terceiro maquinista, ou maquinista superior. Por exemplo, para ter acesso à habilitação como maquinista de terceira categoria, se deveria contar com 180 dias de navegação como ajudante a bordo, com certificado de boa conduta, ser maior de 20 anos e ter tido uma entrevista

\footnotetext{
${ }^{24}$ Esta é mais uma denominação para a qual não encontramos um termo similar em português. Este operário, responsável pelas ferramentas e outros utensílios, pode ser considerado um auxiliar do maquinista. [Nota da tradutora.]

${ }^{25}$ Boletín del Obrero Mecánico. Año II, no 8, agosto 1900

${ }^{26}$ Recopilación de antecedentes... tomo 5, p. 1 a 16.

27 Boletín del Obrero Mecánico. Año II, no 1, enero 1900, pp. 2 a 5.

${ }^{28}$ Boletín del Obrero Mecánico. Año II, no 8, agosto 1900.
} 
com a comissão examinadora, presidida pelo Prefeito-Geral. Deveria também prestar um exame, com uma parte oral e outra escrita, que incluía exercícios de aritmética, geometria e informação de máquinas a vapor e caldeiras. O diploma de maquinista de primeira exigia também 360 dias de navegação como maquinista de segunda, e demonstrar conhecimentos práticos de desmontagem, ajuste e montagem de uma máquina, realizar sua limpeza interna e saber sobre os materiais de sua construção, soldagem e características ${ }^{29}$.

Em geral, em cada embarcação havia um maquinista, cujo nível de formação dependia do tipo, função, tonelagem e potência da máquina do barco. Por exemplo, as embarcações menores requeriam só um condutor de máquina, que obtinha seu certificado depois dos três anos de experiência foguista, além de saber ler e escrever. No outro extremo se encontravam os maquinistas superiores, requeridos em navios de passageiros de ultramar com máquinas de mais de 2.500 c.f. Entre essas duas situações existia uma escala de possibilidades.

Junto com o maquinista havia outros trabalhadores: ali estavam os pañoleros, encarregados das ferramentas e materiais, e os caldeireiros, que alimentavam de água as caldeiras. A maioria dos trabalhadores desta seção estava composta pelos foguistas, cuja tarefa principal era alimentar o fogo do motor. Ao carregar, ativar, retirar, tapar e apagar o fogo das caldeiras, possibilitava o seu funcionamento. Também havia os limpadores, a categoria mais baixa entre a tripulação de máquinas.

Com o surgimento de outros tipos de motores, tornaram-se necessários novos ofícios e especialistas, como os eletricistas e engraxadores. Os primeiros eram trabalhadores qualificados com certificado habilitador, encarregados da manutenção dos equipamentos elétricos a bordo, enquanto os engraxadores ajudavam o maquinista nas tarefas de controle e manutenção do maquinário.

\section{OUTRAS SEÇÕES E OFÍCIOS A BORDO}

A seção de cozinha estava ligada à atenção dos camarotes e da cozinha do barco, seja dos passageiros, seja da própria tripulação. Esta se achava conformada por

\footnotetext{
${ }^{29}$ Recopilación de antecedentes...
} 
um mordomo, cozinheiros, moços, auxiliares, camareiros e pessoal de serviço, que eram os únicos dispensados da condição de saber nadar para serem contratados a bordo $^{30}$.

O pedido de mantimentos e o controle de estoque, assim como a elaboração do cardápio, estavam a cargo do primeiro moço. Também havia moços e auxiliares que realizavam as tarefas de limpeza da cozinha e dos instrumentos utilizados, dos refeitórios, corredores e camarotes, e ao mesmo tempo colaboravam com a preparação do serviço. Em algumas tripulações se somavam despenseiros encarregados da administração e do inventário dos suprimentos a bordo.

Ao adotar-se o telégrafo foi criada a seção de comunicações, composta por um ou mais operadores, encarregados de manter e monitorar a estação de rádio. A Lei de Instalações Radiotelegráficas foi sancionada pelo Congresso da Nação em abril de 1913, mediante a qual se estipulou que as comunicações deste tipo ficariam a cargo do Estado. Estabelecia como obrigação para todo navio de mais de 50 pessoas (entre tripulantes e passageiros) possuir um aparelho ou telégrafo e uma pessoa capacitada para sua utilização.

As embarcações que entravam nos portos ou rios argentinos tinham também a obrigação de levar um baqueano ou um prático, de acordo com o tipo de embarcação e sua tonelagem ${ }^{31}$. O baqueano era um conhecedor das qualidades de uma determinada zona fluvial, de seus canais e rios, picadas e banhados. Especializado nos temas relacionados com as rotas fluviais e a geografia de uma região particular, o baqueano assessorava o capitão ou o patrão de uma embarcação em sua travessia, em certos trechos difíceis de navegar, ou na entrada de determinados portos. Para poder realizar este trabalho tinha de obter o título correspondente, para o qual existiam duas opções. A primeira consistia em provar pelo menos cinco anos de experiência prática, sendo argentino, menor de 65 anos e possuir conhecimentos de leitura e escrita. Com relação a este último requisito, se não soubesse ler e escrever tinha um ano para aprender e voltar a fazer o exame. A outra possibilidade era fazer um exame perante uma comissão composta por práticos dos portos da zona, o qual consistia em demonstrar na prática o manejo de luzes de navegação, reboque e ancoragem, timão e

\footnotetext{
${ }^{30}$ TRONCOSO, Oscar. Fundadores del gremialismo obrero. Vol. 1. Buenos Aires: CEAL, 1983, p. 56.

${ }^{31}$ Recopilación de antecedentes... Reglamento del Puerto de Buenos Aires, 15 febrero 1894.
} 
telégrafo, manobra de âncoras, medição de calados e conhecimentos de embarcações menores, regulamentação de apitos, manobras diurnas e noturnas, canais e ações diante de coalizão ou abordagem ${ }^{32}$.

Os práticos eram aqueles especialistas que dirigiam o rumo das embarcações para que, ao entrarem no porto, o fizessem de forma segura. Este era, e é ainda hoje, um trabalho de grande qualificação, que requeria conhecimento pormenorizado das características do rio ou do porto em questão. Todos os avanços tecnológicos existentes, faróis, balizas, satélites, radares, pilotos automáticos, para mencionar alguns, não puderam suplantar este ofício altamente qualificado e, portanto, escasso. Para ascender a este posto era necessário ter uma formação prévia como capitão e se submeter a um extenso exame na Prefeitura. Como responsáveis por entrar ou tirar os navios dos portos aos quais eram designados, sua profissão e habilitação eram reguladas pelo Estado. O exame pelo qual obtinham esta habilitação estava a cargo da Prefeitura, e para prestá-lo, além de comprovarem conhecimento pormenorizado das características do porto ao qual seriam designados ou a via navegável à qual iam empenhar-se em sua tarefa, era necessário poder averiguar o calado (medir a profundidade) do rio ou canal, para melhor manobrar os navios ao entrar e sair do porto ou ao adentrar pelos rios interiores.

A praticagem era um serviço remunerado de acordo com as características da embarcação. As tarifas, assim como outras disposições gerais do ofício, foram estipuladas pelo Regulamento Geral de Práticos, sancionado por decreto presidencial em 1905. Um novo regulamento, sancionado em 1917, estabeleceu a jurisdição única como área de competência do prático, especializado em uma zona ou porto em particular. Além disso, fixava a quantidade necessária de práticos por jurisdição. Por exemplo, no porto de Buenos Aires eram empregados 40 práticos, no rio da Prata, 70, um número similar ao do rio Paraná, enquanto ao rio Uruguai destinavam-se 10 práticos. Os práticos se organizaram desde o início do século na Sociedade Corpo de Práticos da Argentina, cujos estatutos e personalidade jurídica foram aprovados por decreto presidencial em $1904^{33}$.

\footnotetext{
${ }^{32}$ Recopilación de antecedentes... Decreto del Ministerio de Marina, 2 mayo 1911, ordenanza de Prefectura del 10 de mayo de 1911.

${ }^{33}$ CLIMENT, A. G. y CLIMENT, A. G. op. cit.
} 
As tarefas e funções que caracterizavam o trabalho a bordo se tornavam mais complexas e diversas caso se tratasse de um navio de passageiros, multiplicando-se o pessoal de serviço e o administrativo, assim como aquele pessoal encarregado de áreas recreativas e médicas. A organização do trabalho a bordo se caracterizou também pela variada conformação da tripulação, em número e tarefas, de acordo com o tipo de embarcação, tonelagem, função e destino, assim como pela potência da máquina que a impulsionava. Por exemplo, por ordem da Prefeitura, em 1915, um navio de 100 toneladas de registro deveria ter uma tripulação de 18 homens, incluído o capitão. No entanto, para cumprir com uma jornada de trabalho de oito horas, a mesma embarcação precisava de um total de 27 tripulantes. Contra toda regra, um barco de 200 toneladas podia perfeitamente zarpar com 16 tripulantes a bordo, incluindo o capitão, o primeiro e o segundo oficiais, três maquinistas, um contramestre, seis marinheiros, um foguista, um cozinheiro e um moço, como de fato ocorria sem sanção legal ${ }^{34}$.

Outra característica do trabalho marítimo foi a marcada diferenciação entre a tripulação e a oficialidade, apreciável tanto nas tarefas diárias, nos saberes requeridos, assim como também em sua organização sindical. As diferenças hierárquicas e a estruturação piramidal do trabalho a bordo se destacam como traços característicos da organização do trabalho, expressos nos registros do censo e formados em extensas escalas salariais. Talvez seja essa uma das características mais importantes do trabalho marítimo, com relação a outros tipos de trabalho, como, por exemplo, o que podiam desempenhar trabalhadores de uma fábrica, da administração pública ou de uma empresa privada. Cotidianamente, na vida e nas tarefas a bordo, estava presente esta diferença: oficiais e tripulantes habitavam e trabalhavam em espaços diferenciados, comiam e dormiam em lugares distintos. Mesmo estando no mesmo navio, um maquinista podia não ver o chefe de máquinas durante vários turnos, ou mesmo um marinheiro ou qualquer outro tripulante com relação ao capitão.

A diferenciação hierárquica e de categorias entre os trabalhadores embarcados, como foi mencionado, estava expressa na forma de nucleamento sindical que estes desenvolviam. A organização mais importante da tripulação foi a FOM, a qual agrupou

\footnotetext{
${ }^{34}$ RUSSO, Luis Ario. La marina mercante argentina. Buenos Aires: Instituto de Economía de los Transportes, FCE-UBA, 1938, p. 216-221.
} 
desde a sua formação, em 1910, marinheiros e foguistas, e incorporou com o tempo a moços e patrões, contramestres, condutores e ajudantes. Cada uma dessas categorias manteve seu sindicato, considerado uma seção dentro da estrutura federativa da FOM, composta por outras seções geográficas, como Campana, San Nicolás, Rosário, Gualeguaychú, Bahía Blanca etc.

A FOM participou em muitas das lutas operárias gerais mais significativas do período e impulsionou uma série de greves gerais e parciais no setor, sob a direção da corrente sindicalista ${ }^{35}$. Fê-lo muitas vezes, e de forma exitosa, entre 1916 e 1921, conjuntamente com os sindicatos da oficialidade, entre os quais estiveram o Centro de Capitães de Ultramar, a Sociedade de Práticos e Baqueanos, o Centro de Maquinistas Navais, o Centro de Comissários Navais e o Centro de Radiografistas ${ }^{36}$. Esta unidade contradizia a disciplina do trabalho a bordo, baseada na aplicação e respeito às hierarquias e responsabilidades, invocada pelas empresas e suas organizações e sancionada pela regulamentação existente. Esta aliança possibilitou a unidade de sanção que resultou vital para o controle sindical da organização do trabalho. 0 controle operário efetivo sobre o trabalho teve como eixo a sanção conjunta e solidária dos capitães. Estes, junto com os maquinistas, foram atores centrais, dado que era o pessoal mais qualificado e os responsáveis não só da navegação, mas também pela seleção do pessoal idôneo para as diversas seções e categorias.

A mesma organização hierárquica do trabalho a bordo, se suscitou conflitos reiterados, também gerou determinados consensos. Estes consentimentos básicos, consolidados e compartilhados pelas tripulações, pelos oficiais e pelas organizações sindicais de ambos, foram também adotados pelas empresas e pelo Estado. Uma das noções básicas foi a existência da hierarquização de tarefas e funções, assim como a necessária disciplina e respeito a essa estrutura. O fundamento deste consenso estava dado pela consciência de que, na viagem, uma falha, um descuido ou a falta de acordo podiam ter consequências perigosas: a sobrevivência dava sentido à organização piramidal. Isso fez com que a existência de uma hierarquia e a figura do capitão e das demais partes desta estrutura piramidal não fossem questionadas pelas organizações sindicais nas quais participavam os trabalhadores marítimos, deixando espaço assim

\footnotetext{
${ }^{35}$ Ver nota 1.

${ }^{36}$ Boletín de La Unión del Marino. no 21, 9 junio 1920.
} 
para a unidade e a solidariedade. O chamado à tripulação para sustentar uma atitude tolerante e disciplinada, e a manter o "respeito ao superior, sem que os vejais obrigados a rebaixar vossa própria dignidade", foi realizado a partir das páginas do periódico sindical, junto com a apelação a oficiais e tripulantes subalternos a que "sejais tolerantes, no amplo sentido da palavra, no cumprimento de vossos respectivos $\operatorname{cargos}^{\prime 37}$. Ao mesmo tempo, estimulavam-se os oficiais a sustentar a unidade de ação sindical contra a patronal, contra os muitos oficiais da marinha mercante que possuem ainda, seja por falta de cultura e consciência sindical ou por qualquer outro prejuízo de classe ou favoritismo patronal, certo espírito de desconfiança para com seus respectivos sindicatos ${ }^{38}$.

O ditado popular que afirmava "onde capitão manda, não governa marinheiro" faz referência às fortes determinações da hierarquia e da disciplina na vida e no trabalho a bordo, intrínsecas ao trabalho a bordo e compartilhadas pelos que dela participam. De todas as formas, a ação sindical conjunta e a unidade entre a oficialidade e a tripulação conseguiram colocar em primeiro plano outro tipo de tensões, já não aquelas próprias do trabalho nas diferentes embarcações, mas o enfrentamento comum contra o segmento patronal. Em resumo, a hierarquia foi um elemento central na organização do trabalho a bordo, considerado como tal pelas organizações sindicais dos diversos trabalhadores e do pessoal hierárquico marítimo. No entanto, tal diferenciação entre seções no interior de cada uma destas não impediu a unidade de ação, a qual se desenvolveu durante o período mais conflituoso, entre os anos de 1916 e 1921. Durante as greves marítimas dirigidas pela FOM, em dezembro de 1916, abril de 1917, janeiro de 1919 e durante todo o ano de 1920, participaram marinheiros, foguistas e moços aliados com os capitães e maquinistas. Além de sustentar uma unidade de ação, conseguiram em várias oportunidades constituir um Comitê de Greve, como ocorreu em 1919 e 1920. A aliança desenvolvida nesses anos pelos sindicatos da tripulação, a oficialidade e outros trabalhadores qualificados enfrentou as condições de trabalho dolosas impostas a bordo pelas empresas, as quais foram em parte revertidas através da organização e da luta conjunta.

\footnotetext{
${ }^{37}$ LUM no 59, enero 1920, "Reflexiones del momento. La disciplina"; Welko Denda.

${ }^{38}$ LUM no 55, septiembre 1919, "Un llamado a los oficiales"; Welko Denda.
} 


\title{
OS PROBLEMAS DA GENTE DE MAR:
}

\section{TRABALHOS, DESCANSO E REGULAMENTAÇÃO}

\begin{abstract}
Marinheiros que vivem entre máquinas... Foguistas, homens de mar... que por virtude de tais, têm predisposição de aprender mais que aquele trabalhador que nunca saiu de sua aldeia ${ }^{39}$.
\end{abstract}

O trabalho marítimo, organizado da forma antes descrita, teve como base objetiva o barco, cujo processo de trabalho definiu tarefas, ritmos e funções, intensidades, jornadas e condições, objetos de diversas regulamentações e leis. No entanto, as condições de trabalho nas embarcações não se ajustavam a sua letra. Muito pelo contrário, os montantes e a forma dos salários, o contrato, a jornada de trabalho, a habilitação, alimentação e alojamento a bordo, entre outras, foram campo de disputa entre as empresas e os trabalhadores, os quais, a partir de suas organizações sindicais atuaram em prol da reversão das deterioradas condições de trabalho que predominavam no início do século e, sobretudo, nos anos da Primeira Guerra Mundial.

Neste sentido, uma das primeiras conquistas da Sociedade de Marinheiros e Foguistas foi, em 1904, abolir o costume das empresas de obrigar o trabalhador de uma embarcação particular a trabalhar em distintos navios da mesma companhia. A partir de então, cada tripulação só deveria se envolver nas tarefas da embarcação para a qual foi contratada ${ }^{40}$.

As companhias de navegação costumavam responsabilizar os operários pelos defeitos ou danos, impondo multas que descontavam dos seus salários. Situação similar ocorria diante do desaparecimento ou roubo dos instrumentos ou da carga das embarcações. Então, a empresa tentava fazer com que os trabalhadores pagassem a perda, como ocorreu nos vapores Helios e Berna, da empresa Mihanovich, onde se tentou que serenos e timoneiros pagassem pelo desaparecimento de relógios da sala de comandos, o que foi evitado pela oposição unânime de delegados da FOM e da Sociedade de Capitães e Práticos ${ }^{41}$.

\footnotetext{
${ }^{39}$ LUM no 7, 23 de agosto 1911.

${ }^{40}$ Boletín del DNT no 40, febrero 1919.

${ }^{41}$ LUM no 54, agosto 1919, p. 3.
} 
As formas de contratação das tripulações se caracterizaram por uma alta informalidade, a partir do conhecimento mútuo e mediante contratos de palavra ${ }^{42}$. 0 único requisito que se impunha ao começar o século $X X$ era o de possuir uma caderneta de navegação expedida pela Prefeitura. Em geral, os trabalhadores eram contratados pelos patrões, capitães ou pilotos, "que sabem escolher a tripulação... a partir da recomendação ou do conhecimento prévio" ${ }^{43}$. Existiam também contratadores ou corretores de embarques, intermediários que, em troca de uma comissão de não mais de $8 \%$, aproximadamente, os localizavam em alguma embarcação, consistindo porém numa minoria. Abundavam os casos nos quais o contato se dava entre conhecidos, vizinhos, membros da mesma coletividade ou comunidade de origem, ou outras formas de relação direta ${ }^{44}$.

Em matéria de salários, existiu uma escala correspondente à hierarquia e à estratificação das tarefas. O informe de Juan Alsina ${ }^{45}$, realizado no ano de 1905 , dava conta dos montantes salariais e das distâncias existentes entre um marinheiro, que recebia entre $\$ 40$ e $\$ 60 \mathrm{~m} / \mathrm{n}$ ao mês, e um capitão, cujo pagamento oscilava entre os $\$ 250$ e $\$ 300 \mathrm{~m} / \mathrm{n}$, cinco vezes mais que os tripulantes de coberta. Um prático podia superar os $\$ 300 \mathrm{~m} / \mathrm{n}$. Enquanto um chefe de sala de máquina ganhava entre $\$ 150$ e $\$ 230 \mathrm{~m} / \mathrm{n}$, um foguista não superava os $\$ 80 \mathrm{~m} / \mathrm{n}$. Na seção cozinha, o encarregado ou cozinheiro podia ganhar $\$ 80 \mathrm{~m} / \mathrm{n}$, um moço em torno de $\$ 50 \mathrm{~m} / \mathrm{n}$, e um lava-pratos menos da metade.

No ano de 1908, o salário médio de um marinheiro continuava rondando os $\$ 60 \mathrm{~m} / \mathrm{n}$, mantendo-se as proporções e escalas antes mencionadas ${ }^{46}$. A situação se agravou ainda mais com a baixa salarial de $\$ 10 \mathrm{~m} / \mathrm{n}$, realizada pelas empresas ao começar a Grande Guerra, o que prejudicou o salário nominal, enquanto o salário real vinha se deteriorando pelo aumento dos preços em pleno conflito bélico. Esta foi uma das queixas que impulsionaram a greve geral os trabalhadores marítimos do final de 1916.

\footnotetext{
42 STORNI, Pablo. "La industria y la situación de las clases obreras en la capital de la república". Informe presentado a Joaquín V. González como antecedente para la preparación del Proyecto de Ley Nacional del Trabajo. Revista Jurídica y de Ciencias Sociales. Año XXV, enero-febrero 1908, Buenos Aires, Tomo 1, no 1 y $2,1908$.

${ }^{43}$ Boletín DNT no 6, septiembre 1908, p. 368.

${ }^{44}$ Boletín DNT no 6, septiembre 1908.

${ }^{45}$ ALSINA, Juan. El obrero en 1905 . tomo 2, cap. 9.

${ }^{46}$ Boletín DNT no 6, Septiembre 1908, p. 367.
} 
Diariamente, a maioria dos tripulantes realizava horas extras, cujo pagamento variava de acordo com o tipo e função de embarcação (trabalho noturno, domingos e feriados $)^{47}$. Ao somar as horas extras trabalhadas, o salário médio mensal de um marinheiro embarcado se aproximava dos $\$ 80 \mathrm{~m} / \mathrm{n}$. Se considerarmos que o custo de vida para uma família operária, calculado pelo DNT no ano de 1911 , era de $\$ 93,05 \mathrm{~m} / \mathrm{n}$ (incluindo aluguel, alimentos, roupa e lavado), fica evidente que um marinheiro que ganhava em média entre $\$ 60$ e $\$ 65 \mathrm{~m} / \mathrm{n}$ de salário básico estava claramente obrigado a trabalhar horas extras. O aperto salarial levava também a comprar produtos nos armazéns próximos ao porto através de um sistema de cadernetas, o que muitas vezes resultava num crescente endividamento ${ }^{48}$.

Sendo necessárias as horas extras para completar o salário dos trabalhadores embarcados, aparecem em reiteradas oportunidades queixas na imprensa sindical sobre o atraso ou a falta de pagamento destas, sob a responsabilidade dos armadores e com a intermediação de capitães e oficiais ${ }^{49}$. Outra demanda salarial foi a exigência de incluir como horas extras o pagamento das tarefas de salvamento, indispensáveis nos casos de acidentes ou naufrágios ${ }^{50}$. Assim, o descumprimento do pagamento salarial em tempo e forma foi uma constante nesses anos. Casos como o do vapor Deseado, no qual seu proprietário "não pôde ser mais avarento do que é, pois de três a quatro meses que deve aos foguistas, quando estes iam reclamar seus salários, Ihes oferecia cinco ou dez pesos para ir 'tirando', como ele disse..." eram frequentes ${ }^{51}$.

O descanso dominical foi também uma demanda operária constante até 1905, quando foi sancionado por lei, e os operários em geral, junto com os marítimos, passaram a exigir o cumprimento da lei em questão ${ }^{52}$. Quando não se encontravam cumprindo turnos de trabalho, os operários embarcados se dedicavam a "fazer rancho", isto é, a passar o tempo livre em seus camarotes ou ranchos ou nos espaços comuns habilitados, ou a descansar. Mas isso ocorria na menor parte do dia. Se houve a tendência de estabelecer uma jornada de oito a nove horas, de acordo com a seção,

\footnotetext{
${ }^{47}$ STORNI, Pablo op. cit.

${ }^{48}$ Boletín DNT no 19, diciembre 1911.

49 LUM no 43, octubre 1916, "Notas y comentarios de la vida de a bordo".

${ }^{50}$ LUM no 67, septiembre 1920.

51 LUM no 44, noviembre 1916, p. 4, "Vapor Deseado" y "Vapor Mar del Plata".

52 PANETTIERI, José. Las primeras leyes obreras, Buenos Aires: CEAL, 1984. El descanso dominical fue sancionado como ley no 4.661 en agosto de 1905.
} 
a jornada de trabalho de um foguista ou de outro trabalhador de sala de máquinas nos primeiros anos do século se aproximava das doze horas, o mesmo que na coberta. É sintomático o caso ocorrido a bordo de um rebocador de uma pequena empresa, em que

os dois foguistas... desembarcaram porque não puderam tolerar por mais tempo o abuso dos quais eram vítimas, obrigando-os a trabalhar jornadas brutais, como são as de doze horas por dia. [A embarcação saiu do porto] à vista e paciência das autoridades marítimas com um só foguista, fazendo o trabalho de foguista o senhor maquinista e um traidor no nosso sindicato, que figura como $\mathrm{cabo}^{53}$.

Como demonstra a citação anterior, a intensidade do trabalho e a duração da jornada estavam estreitamente relacionadas com a composição da tripulação, ou seja, com a quantidade necessária de pessoal para cobrir os turnos diários. Assim, a questão do pessoal mínimo a bordo esteve desde o início do século regulamentada pela Prefeitura e sancionada por decretos presidenciais, onde se estipulava para cada tipo de embarcação uma quantidade necessária de tripulantes. Isto era o que ocorria, e assim foi analisado pela imprensa sindical:

Não é possível admitir que embarcações de 100 a 1.000 toneladas tenham $1,2,3,4,5$ e 6 marinheiros, respectivamente. Nas lanchas e pontões de porto e rio é onde se nota mais a falta de pessoal. Como admitir que nas lanchas que carregam 300 toneladas haja dois marinheiros que devem trabalhar, e outros de vez em quando, e naqueles que é um só tem de ir cedo ao mercado, ficar todas as noites a bordo, trabalhar e às vezes atender à cozinha?... Com o pessoal de máquinas ocorre outro tanto. Há buques que têm 3 ou 4 senhores fornos com um foguista que deve permanecer quatro horas contínuas em frente a eles, sem descansar um instante de manejar a pá, o nodo e a barra. Pela escassez de carvão é queimada lenha, e ocorre geralmente que o foguista deve usar pedaços de quebracho que têm peso de 70 a 80 quilos, e para o que queimou esta classe de lenha sabe o que é fazer uma guarda ${ }^{54}$.

No seu informe de 1904, Pablo Storni também denunciava a ausência da quantidade necessária de trabalhadores a bordo, o que sobrecarregava o trabalho dos embarcados e piorava as condições e ritmos de trabalho, aumentando as possibilidades e probabilidades de acidentes ${ }^{55}$. O reiterado descumprimento das empresas quanto à quantidade mínima de tripulantes por seção levou ao conflito com

\footnotetext{
${ }^{53}$ LUM no 44, noviembre 1916.

54 LUM no 67, septiembre 1920, “Necesidades de nuestra organización” Eduardo Pereyra.

55 STORNI, Pablo. op. cit.
} 
os sindicatos marítimos, os quais também tiveram de enfrentar as tentativas patronais de reduzir o número de pessoal ${ }^{56}$.

Quanto aos acidentes de trabalho, durante os primeiros anos do século XX foram frequentes e produto de variadas causas. A segurança da viagem dependia de múltiplos fatores, entre eles, a construção e a manutenção do buque, sua conservação e estabilidade, limpeza e calafetação do casco, o respeito ao limite de carga, entre outros $^{57}$. As condições de segurança a bordo não parecem ter sido satisfatórias, já que cumprir com todos os cuidados e disposições implicava para os armadores um enorme gasto, que nem sempre se viam obrigados a realizar, já que era evidente a falta de inspeção e de sanções por parte das autoridades estatais.

O periódico sindical abordava a falta de elementos de salvamento para a segurança do pessoal, devido à "avareza dos armadores e por uma despreocupação absoluta com os que arriscam suas vidas a bordo". Denunciava assim o descumprimento das ordens existentes, e tais equipamentos só eram conseguidos mediante a paralisação do trabalho pelas tripulações sindicalizadas.

\begin{abstract}
Não é possível desprezar assim as vidas em benefício da patranha capitalista: porque uma coisa é estar em terra, no firme, e outra coisa é viver horas de angústia em meio ao mar, onde não há ramos para se agarrar... [Sem botes nem salva-vidas, os barcos zarpavam sem levar a bordo] saco de bolacha, o barril de água doce, o compasso, as velas, o machado, foguetes, faróis e todo o necessário no caso de naufrágio ${ }^{58}$.
\end{abstract}

Barcos que zarpavam quase completamente desprovidos dos elementos de salvamento, sem cumprir com as precauções e normas de segurança a bordo, navegavam e realizavam suas tarefas de frete descumprindo as regulamentações, com a anuência da Prefeitura e Aduana em muitos casos. Ainda que o seguro por acidente fosse obrigatório desde 1903, as faltas e descumprimentos por parte das empresas foram a norma. Os armadores deviam pagar aos trabalhadores acidentados durante o tempo que não pudessem embarcar, mas na prática este montante era descontado dos salários do resto da tripulação. A indenização também só cobria acidentes ocorridos nas horas de trabalho, e muitas vezes só se colocava em prática em caso de

\footnotetext{
${ }^{56}$ LUM no 84, abril 1922, no 86, junio 1922.

${ }^{57}$ FOLD MORELL, R. "Las condiciones de vida a bordo". In: AA.VV. Introducción a la historia marítima. Buenos Aires: Fundación Argentina de Estudios Marítimos, 1978.

${ }^{58}$ LUM no 67, septiembre 1920, “Necesidades de nuestra organización”. Eduardo Pereyra.
} 
morte ou de graves consequências ${ }^{59}$. A lei sobre acidentes de trabalho, sancionada em $1915^{60}$, teve uma aplicação efetiva paulatina, sendo objeto de múltiplos questionamentos por parte dos sindicatos marítimos. Eram frequentes as denúncias de varações, defeitos e demais acidentes em viagem, causados pela imperícia dos oficiais; a falta de formação e capacitação, o excessivo trabalho, em intensidade e quantidade de horas diárias, o reduzido espaço na sala de máquinas e o cansaço pelas jornadas excessivas.

Os espaços habitáveis a bordo, âmbitos comuns e privados, estavam regidos por modos e critérios que determinavam seu desenho, configurados em regulamentações que estabeleciam os modos de sua construção. $O$ reduzido espaço para o alojamento da tripulação era um dos mais frequentes descumprimentos a essas regras de habitabilidade, junto com a falta de ventilação e de uma iluminação adequada, entre outras ${ }^{61}$. Por exemplo, a necessidade de mesas para "fazer rancho" e de banheiros para os foguistas, os quais com sorte e só dependendo da boa vontade do superior podiam utilizar os banheiros destinados aos maquinistas, foi denunciada na carta de condições da greve de 1911. No entanto, ainda em 1916 fazia parte das demandas operárias que levaram o sindicato marítimo à greve ${ }^{62}$. Os camarotes individuais estavam disponíveis somente para a oficialidade. A tripulação, contudo, devia situar-se em espaços reduzidos. Um artigo do La Unión del Marino, entre muitos, denunciava:

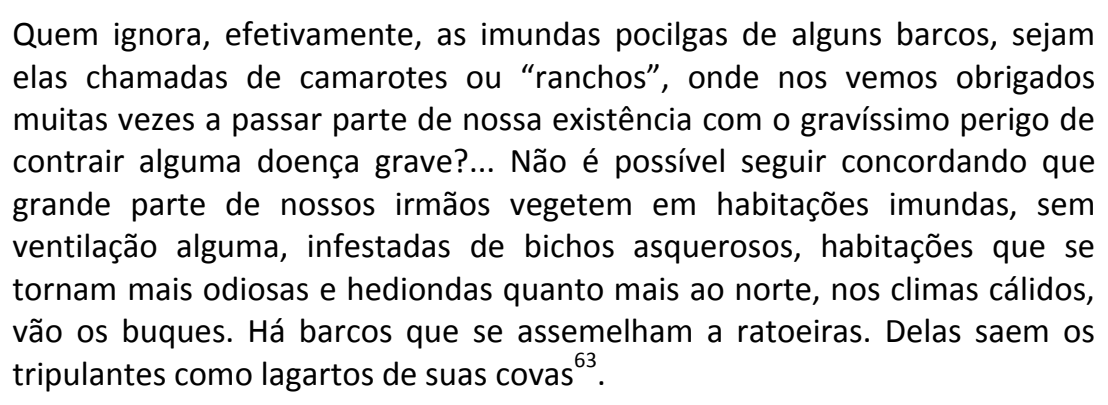

Nessas condições era comum a proliferação de diversas doenças a bordo, entre as que se mencionam com mais frequência, a tuberculose, a febre amarela, as doenças

\footnotetext{
59 STORNI, Pablo. op. cit.

${ }^{60}$ PANETTIERI, José. op. cit. La ley sobre accidentes de trabajo no 9.688 fue sancionada en octubre de 1915.

${ }^{61}$ Storni, Pablo. op. cit.

62 Boletín DNT no 37, marzo 1918.

63 LUM no 71, enero 1921, “Acción conjunta y futuro de nuestra organización”. Welko Denda.
} 
venéreas e o alcoolismo ${ }^{64}$, tendo sido descartado o escorbuto. A essas doenças se somavam aquelas relacionadas com fatores psicológicos, causadas pelo desarraigamento, a ansiedade do momento do desembarque diante da possibilidade do dever de permanecer a bordo se não aparecia o relevo, e ter de continuar em viagem, ou também ante a preocupação, que em determinadas conjunturas se tornava uma certeza, de desembarcar sem ter ainda contrato para uma nova viagem neste ou noutro barco ${ }^{65}$.

Tanto a água potável quanto os alimentos eram condições essenciais para o trabalho em viagem, e objeto de racionamento. Uma das demandas reiteradas dos sindicatos marítimos, expressas nas greves de $1911^{66}$ e 1916 , foi o que eles consideravam uma alimentação "sadia, abundante e variada, composta por três pratos e pão fresco, e a substituição do vinho Carlón pelo San Juan ou Francês" ${ }^{\prime 67}$. Em dezembro de 1916, foi incluída a provisão de um litro de vinho Mendoza, a eliminação dos intermediários no fornecimento dos alimentos e a transferência desta responsabilidade aos cozinheiros. A má alimentação e as péssimas condições existentes antes da greve de 1916 levaram ao fato de que um dos marinheiros do vapor Mar del Plata, "indignado com a péssima e insuficiente alimentação que se dava no buque, juntou o jantar e em um pacote postal e a enviou ao presidente do diretório" $^{68}$. O artigo denunciava que a causa do deficiente suprimento fora a especulação e o monopólio dos insumos por parte do capitão, situação que se repetia nas embarcações das diversas frotas. A imprensa sindical afirmava que

\begin{abstract}
...os que ignoram a triste situação em que se encontram os párias de bordo, foguistas e marinheiros, não poderão senão justificar a necessidade imperiosa de pôr um limite à rapacidade de provedores mordomos, e até capitães pouco escrupulosos que crescem até com a comida dos infelizes trabalhadores de bordo, que não hesitam em roubar descaradamente o que os armadores estipulam para a manutenção de seus operários ${ }^{69}$.
\end{abstract}

Foram também frequentes naqueles anos as queixas pela realização de tarefas alheias ao ofício. Neste caso se dava a negativa de marinheiros e foguistas a realizar

\footnotetext{
${ }^{64}$ LUM no 58, diciembre 1919.

${ }^{65}$ Entrevista realizada em julho de 2008, com Alberto Lorenzo, limpador e depois eletricista, filho e neto de marinheiros espanhóis provenientes da região do Cabo Finisterra, Galiza, Espanha.

${ }^{66}$ LUM no 7, 23 agosto 1911.

${ }^{67}$ Boletín DNT no 19, diciembre 1911.

${ }^{68}$ LUM no 44, noviembre 1916, p. 4.

${ }^{69}$ LUM no 43, octubre 1916; no 44, noviembre 1916; no 56, octubre 1919.
} 
tarefas de carga, lavar os costados do barco, e se encontram diversos protestos contra as demissões. Foguistas que se negam a cumprir a ordem do capitão de realizar o transbordo de lenha e de estivá-la nas carvoeiras, ou a transportar canastras de verduras da proa à popa; chefes maquinistas que lhes exigem que pintem as chaminés do buque; marinheiros despedidos por se negarem a transportar os equipamentos de uma companhia teatral, como exigia o capitão, são só alguns dos exemplos citáveis ${ }^{70}$.

Com relação às qualificações, uma das exigências habituais entre os trabalhadores marítimos foi a implementação dos exames de aptidões e conhecimentos, tanto para o pessoal de máquinas como para o de coberta, estabelecendo um período de aprendizagem prévio $^{71}$.

Por que não se exige que em todos os buques haja aprendizes do trabalho a bordo? Exigir aprendizes para marinheiros e foguistas é contribuir para que se valorize o trabalho, exigindo que para a seção de máquinas tenha pelo menos um ano de moço, e ao passar o faria como carvoeiro e ir ascendendo, e em seção coberta igual tempo para passar primeiramente a guincheiro e depois a marinheiro. É necessário realizar o ofício para obtê-lo..." ${ }^{\prime 72}$.

As mesmas demandas defendiam os maquinistas, os quais denunciavam reiteradamente o descumprimento da regulamentação existente, quando eram contratados foguistas no lugar de maquinistas, "homens que a duras penas sabem colocar/escrever seu nome e que jamais estiveram em uma oficina"73. A defesa do saber e da formação necessária para o desenvolvimento e a prática das tarefas de maquinista, um trabalho de alta qualificação, se expressou também através do chamado aos trabalhadores menores:

\begin{abstract}
...jovens operários, cabe a vocês batalhar agora para que a regulamentação seja um fato... De que lhes serve a rigorosa aprendizagem em uma oficina durante 10 ou 12 anos? De que lhes serve, depois do cansaço do trabalho diário, sacrificarem-se com estudos noturnos durante horas, prevendo ao longe um futuro risonho?... ${ }^{74}$.
\end{abstract}

A ausência de um regulamento do trabalho a bordo foi um dos traços característicos desses anos, destacado tanto pelas organizações dos trabalhadores como por instituições estatais, e até mesmo, em algumas conjunturas, pelas

\footnotetext{
${ }^{70}$ LUM no 43, octubre 1916; LUM no 54, agosto 1919, p. 3; y LUM no 56, octubre 1919.

71 LUM no 54, agosto 1919, "Resoluciones de la Asamblea de Marineros del 10 de julio"; no 66, agosto 1920 "Necesidades de nuestra organización".

72 LUM no 67, septiembre 1920, "Necesidades de nuestra organización".

${ }^{73}$ Boletín del Obrero Mecánico, 10 noviembre 1900.

${ }^{74}$ Boletín del Obrero Mecánico, 1ㅇ noviembre 1900.
} 
organizações patronais. Dentro do conjunto dos trabalhadores, os marítimos ficavam muitas vezes fora do campo de aplicação das leis existentes para a regulação das condições de trabalho. Assim destacava um importante funcionário do Departamento Nacional do Trabalho, ao afirmar que: "o marinheiro se encontra legalmente menos protegido que o ferroviário ou que o trabalhador de uma fábrica ou usina, pela própria natureza do contrato de trabalho a bordo"75. Durante todo o período foi matéria pendente a constituição e aplicação de uma regulamentação que determinasse claramente as obrigações da tripulação, assim como seus direitos, mas tal situação era similar em outras atividades.

Todos os elementos aqui analisados nos permitem reconstruir uma imagem nítida das condições de trabalho marítimo. O êxito da greve geral marítima de dezembro de $1916^{76}$ resultou na melhoria das condições de trabalho e na consolidação e fortalecimento da FOM, possibilitando-Ihe exercer o controle sobre a organização e condições trabalhistas entre 1916 e 1921. Isso reforçou a melhora substancial das condições gerais de trabalho, só possibilitadas e sustentadas a partir da ação direta impulsionada por esta federação, a qual contou com uma forte adesão dos trabalhadores do setor. Ao mesmo tempo, implicou um nível crescente de enfrentamento com as empresas. Ambos, os trabalhadores marítimos e o patronal naval, desenvolveram um maior nível de organização e de ação, ao mesmo tempo que pressionaram de forma crescente e por diversos meios o Estado Nacional. O conflito operário-patronal derivou na greve parcial que, durante todo o ano de 1920, sustentaram os trabalhadores marítimos contra a empresa Mihanovich.

Diversas ações e medidas de luta impulsionadas pela FOM foram o meio para conseguir e manter o controle sobre o acesso ao posto de trabalho, as condições de trabalho e a disciplina a bordo das frotas de cabotagem do porto de Buenos Aires a partir de $1916^{77}$. A própria organização hierárquica do trabalho marítimo fez com que, para tornar efetivo o controle sobre as condições e o mercado de trabalho por parte da FOM, fosse imprescindível a aliança com as organizações de capitães e demais

\footnotetext{
${ }^{75}$ Boletín DNT № 47, septiembre 1920, p. 32. Informe de Alejandro Unsain.

${ }^{76}$ Boletín DNT no 37, marzo 1918, y no 40, febrero 1919, La Unión del Marino no 44, noviembre 1916.

${ }^{77}$ Um caso semelhante de controle operário se deu entre os operários da construção, e em alguns aspectos, entre os estivadores da cidade de Santos. Ver: SILVA, Fernando Teixeira da. Operários sem patrões. Os trabalhadores da cidade de Santos no entreguerras. Campinas/SP: Editora UNICAMP, 2003.
} 
oficiais, sendo estes parte do pessoal mais qualificado a bordo e, portanto, responsáveis por montar as listagens das diversas tripulações, que deveriam ser informadas à empresa e à autoridade estatal. No entanto, manteve-se o controle sindical, o qual foi enfraquecido logo em 1921.

\section{A MODO DE CONCLUSÃO}

A reconstrução histórica do processo e organização do trabalho a bordo aqui esboçada tem, necessariamente, um tom descritivo. Tentou-se amalgamar dados e descrições com a análise dos problemas fundamentais relacionados, para aprofundar o conhecimento e a reflexão sobre os temas relativos ao trabalho marítimo na última década do século XIX e nas primeiras do século XX, em particular, sobre o processo e a organização a bordo como primeiro elemento explicativo das condições de trabalho e dos conflitos resultantes, assim como sua incidência na organização operária e na dinâmica da unidade entre diversas categorias de trabalhadores marítimos.

Da análise anterior decorrem algumas afirmações nodais relacionadas com o trabalho marítimo, sua organização e processo de trabalho. Um primeiro elementochave no estudo do trabalho marítimo constitui a série de mudanças e inovações na sua base material, incorporadas pelas empresas em função do aumento da produtividade do trabalho. Os mais destacados foram a navegação a vapor, a construção metálica do casco e da estrutura do barco, e a substituição da máquina a vapor por outros motores, como o de combustão interna. Esta mecanização progressiva do processo de trabalho teve como resultado o desaparecimento de determinadas tarefas a bordo e o surgimento de outras, e dos trabalhadores atrelados a estas, como foi o progressivo desaparecimento dos calafates, dos carvoeiros, caldeireiros e foguistas, e a incorporação dos engraxadores, eletricistas, entre outros. Foram incorporadas novas seções inteiras, como a de comunicações. Se a mudança da navegação a vela para a navegação a motor foi substancial para a tripulação de coberta, esta não foi mais afetada por inovações posteriores, como ocorreu com a sala de máquinas. A seção de cozinha foi a menos implicada pelas mudanças no processo e na organização do trabalho. Essas transformações, e a consequente redução da 
tripulação necessária, deram lugar a uma grande quantidade de reclamações e de ações por parte dos operários embarcados e de suas organizações.

Segundo, a bordo de vapores e veleiros, o trabalho de milhares de operários se organizou em seções bem diferenciadas, com uma estruturação hierárquica. As principais e perduráveis foram a da coberta, da sala de máquina e da cozinha. No interior de cada uma dessas houve múltiplas categorias e qualificações de trabalhadores, analisadas neste trabalho. Esta forma de divisão do trabalho e de sua organização se estabeleceu sobre uma base material e técnica determinada, que caracterizou o processo de trabalho marítimo. A principal diferenciação estabelecida pela organização do trabalho a bordo foi a existente entre concepção e execução, claramente fragmentada entre a oficialidade e a tripulação, cuja diferenciação no nível do processo do trabalho se reproduziu na sua organização sindical, ao mesmo tempo que a unidade de ação que conseguiram desenvolver em certos períodos superou a diferenciação estabelecida pela experiência do trabalho, como base material de interesses e identidades divergentes, ainda que nem sempre contrapostos.

Desta forma, o traço fundamental da organização do trabalho a bordo foi a hierarquia e a diferenciação estabelecida entre a tripulação e a oficialidade, assim como também no interior das seções mencionadas. A hierarquia que caracterizou a organização do trabalho no interior das embarcações foi considerada um elemento indispensável para a sobrevivência dos embarcados, conceito compartilhado por tripulantes, oficiais, funcionários e empresários, além de tornar possível o desenvolvimento da atividade de navegação comercial com êxito. Esta hierarquia se expressou em uma organização sindical diferenciada, e se houve relações conflituosas a bordo e denúncias contra abusos de autoridade, não chegaram a impugnar a existência dessa diferenciação. Apesar das diversas categorias e seções, houve um consenso geral em torno da organização hierárquica e piramidal do trabalho, estruturada em face da necessidade de respeitar a divisão hierárquica como fator de sobrevivência. No entanto, em certas conjunturas de enfrentamento com as empresas, esta diferenciação não impediu a unidade de ação entre a oficialidade - o pessoal hierárquico e qualificado - e as tripulações, enfrentando de maneira unitária, e por isso eficaz, a hostilidade crescente do patronato. Através dessas ações buscou-se melhorar as condições de trabalho a bordo, como ocorreu durante grande parte do 
período com a habilitação e a segurança, a jornada de trabalho, o pagamento de salários e horas extras, entre outras. A partir de 1916, a luta sindical marítima, demarcada e retroalimentada por uma conjuntura política nacional e mundial de crescente intensidade da luta de classes, foi exitosa. A ação operária, em conjunto com as organizações da oficialidade, impôs novas condições e enfrentou o descumprimento reiterado da regulamentação existente.

Recebido em 08/12/2009

Aprovado para publicação em 17/01/2010 